\title{
Die gebruik van Afrikaanse modale partikels deur voormalige Khoisprekers ${ }^{1}$
}

\author{
C. Jac Conradie \\ Departement Afrikaans, Skool vir tale,Universiteit van Johannesburg, Suid-Afrika \\ E-pos: jacc@uj.ac.za
}

\section{Opsomming}

Die doel van die ondersoek is om te bepaal watter bydrae sprekers of voormalige sprekers van Khoi wat Afrikaans as taal aangeneem het tot die ontwikkeling of gebruik van modale partikels in Afrikaans gelewer het. Bronne wat vir hierdie doel ondersoek is, sluit in aangehaalde uitsprake van Khoi-Khoin uit die laat 17de en vroeg-18de eeu, twee briewe van Khoi-Khoin, 'n onderhoud met 'n Khoi-Khoi soos vryelik weergegee deur C.E. Boniface, koerantbriewe deur persone wat hulle as Khoi-Khoin voorgedoen het, 'n kort drama, die novelle Benigna van Groenekloof of Mamre en ander geskrifte met 'n Genadendalagtergrond, 'n uittreksel uit die dagboek van Hendrik Witbooi, transkripsies van onderhoude wat in die 1980s met Griekwas gevoer is en enkele onderhoude wat in Namakwaland gevoer is. As kontrolekorpus is transkripsies van spontane gesprekke gebruik wat ook in die 1980s in Johannesburg opgeneem is en die standaardtaal verteenwoordig, asook Adam Small se drama Kanna hy ko' hystoe om die variëteit Kaapse Afrikaans te verteenwoordig.

As ons na die grootste bronne kyk, dan blyk dit dat mos verreweg die meeste voorgekom het in tekste met spreektaalkenmerke, met name almal in die onderhoudregister, en dat tog veral sterk staan in oorredende tekste met sterk Nederlandse invloed of konteks. Sommer, maar en darem is ander partikels wat geredelik gebruik is. Die Kanna-drama wyk van die KhoiKhoinbronne en die kontrolekorpus af deur 'n relatief hoë voorkoms van darem. As ons onderskei tussen Nederlandsverwante partikels soos eintlik, maar en tog, enersyds, en tipies Afrikaanse partikels soos darem, mos en rêrig, dan blyk dit dat eersgenoemdes oorwegend voorkom in Benigna en die kontrolekorpus, en laasgenoemdes oorwegend in die ander KhoiKhoinbronne en Kanna. Die Griekwakorpus verskil van die kontrolekorpus deur die hoë frekwensie van die kollokasie mos nou by eersgenoemde teenoor die hoë frekwensie van maar net en nou maar in laasgenoemde.

'n Aantal partikels is ook individueel of in samehang met mekaar ondersoek. Die partikel ja kom byvoorbeeld in 'n hele aantal vroeë aanhalings van Khoi-Khoin-uitings voor, en kan moontlik 'n funksionele voorloper van immers, mos of tog wees, wat ongeveer in dieselfde semantiese veld val. In Benigna en ander bronne uit dieselfde sfeer, wil dit voorkom asof

\footnotetext{
${ }^{1}$ Die Nasionale Navorsingstigting en Universiteit van Johannesburg word hiermee bedank vir steun met die navorsing.
} 
darem nog nie ten volle van daarom gedifferensieer is nie. Daar is aanduidings dat sommer verder van Nederlands zo maar ontwikkel het as fokuspartikel en in emotiewe rigting. Ander partikels wat bespreek word, is maskie, reg(t), juist, kamma, hoeka en netnou.

Samevattend kan gestel word dat voormalige Khoisprekers te oordeel na gebruiksfrekwensie en die gebruik van tipies Afrikaanse partikels, 'n deurslaggewende rol gespeel het in die ontwikkeling van Afrikaanse modale partikels.

Sleutelwoorde: modale partikels, Afrikaans, Kaapse Afrikaans, Nederlands, Duits, Khoi, Khoi-Khoin, kollokasies, spreektaal

\title{
The use of Afrikaans modal particles by former Khoi speakers
}

\begin{abstract}
The purpose of this study is to determine the nature of the contribution made by previous speakers of Khoi who adopted Afrikaans as language to the development or use of modal particles in Afrikaans. Sources studied for this purpose include quoted utterances by Khoikhoin from the late $17^{\text {th }}$ and early $18^{\text {th }}$ century, two letters by Khoikhoin, an interview with a Khoikhoi freely rendered by C.E. Boniface, letters written to newspapers by persons professing to be Khoikhoin, a short play, the novella Benigna van Groenekloof of Mamre and other writings with a Genadendal background, an excerpt from the diary of Hendrik Witbooi, transcriptions of interviews conducted with Griqua in the 1980s and a small number of interviews conducted in Namaqualand. Transcriptions of spontaneous conversations representing the standard language recorded in Johannesburg in the 1980s served as a control, while Adam Small's drama Kanna hy ko' hystoe was added to represent the variety of "Kaapse Afrikaans".
\end{abstract}

If we look at the major texts, it would seem that mos was by far the most frequent particle in sources representing colloquial language, viz. in the interview register, while tog was particularly well represented in persuasive texts with marked Dutch influence or context. Sommer, maar and darem are particles which were also frequently used. The Kanna source departs from the Khoikhoin sources and the control corpus by a having a relatively high occurrence of darem. If we draw a distinction between Dutch related particles such as eintlik, maar and tog, on the one hand, and typically Afrikaans particles such as darem, mos and rêrig, then it appears that particles of the first kind are predominant in Benigna and the control corpus, while particles of the latter kind predominate in the other Khoikhoin sources and Kanna. The Griqua corpus differs from the control corpus in having a particularly high frequency of the collocation mos nou as opposed to the high frequencies of maar nou and nou maar in the latter.

A number of particles were studied individually or in relation to one another. The particle ja occurs in a substantial number of the early quotations of Khoikhoin utterances, and may be a functional precursor of immers, mos or tog, which fall roughly in the same semantic field. In Benigna and other sources from the same background it would seem that darem has not been fully differentiated from daarom. There are indications that sommer has extended its scope from Dutch zo maar towards becoming a focus particle and in an emotive direction. Other particles to be discussed are maskie, reg(t), juist, kamma, hoeka and netnou. 
In sum, it seems clear the former Khoi speakers, judging by frequency of usage and the use of typically Afrikaans particles, have played a crucial part in the development of Afrikaans modal particles.

Keywords: modal particles, Afrikaans, Kaapse Afrikaans, Dutch, German, Khoi, KhoiKhoin, collocations, colloquial language

\section{Inleiding}

Modale partikels (Ndl. schakeringspartikels, Duits Abtönungspartikeln) is 'n adverbiale subgroep waarmee taalgebruikers 'n bepaalde, tipies subjektiewe houding of oordeel aandui of suggereer ten opsigte van verskillende aspekte van hulle eie taaluiting of die gespreksituasie. Wat die uiting as sodanig betref, kan die partikel enigiets van 'n ander leksikale item tot die proposisie in sy geheel kwalifiseer, en wat die situasie betref, kan dit slaan op die gesprekstema van die oomblik, die spreker se persoonlike belang daarby en die spreker se houding teenoor of verhouding met die aangesprokene, en kan dit selfs bepaal word deur die sosiale struktuur waarbinne die gesprek plaasvind.

Afrikaans - soos Nederlands en Duits - maak, veral in die alledaagse gesprek maar ook in geskrewe tekste, baie van modale partikels gebruik. Verskeie Afrikaanse partikels, soos dan, eintlik, juis, die bywoord maar, nou, reeds en tog, is uit Nederlands geërf en kan nog steeds as Nederlandsverwant beskou word. Ander, soos darem, glo, mos en rêrig, is etimologies van Nederlands afleibaar, maar het nuwe funksies of skakerings in Afrikaans aangeneem, en gevalle soos hoeka en kamma is aan Khoi ontleen. Hoewel Afr. sommer 'n reduksievorm van Ndl. zo maar is en semanties in 'n hoë mate daarmee ooreenstem, het dit tog ander gebruikswyses in Afrikaans ontwikkel. Die hoëfrekwensiepartikels nou, toe en dan word uitgesluit uit hierdie ondersoek omdat hulle temporele, modale en diskoersgebruike moeilik uitmekaar gehou kan word en hulle dikwels bloot as stopwoorde gebruik word. ${ }^{2}$

\section{Probleemstelling}

Die vraag wat hier gestel word, is watter bydrae voormalige Khoisprekers (voortaan aangedui as die "Khoigroep") wat Afrikaans as taal aangeneem het (in die lig van hulle belangrike bydrae tot die ontstaan van Afrikaans) tot die ontwikkeling of gebruik van modale partikels in Afrikaans gelewer het. Die term "voormalige" word baie ruim gebruik, aangesien dit dikwels nie bekend is of agterhaal kan word of 'n bepaalde persoon of groep nog Khoi magtig was of nie. Om die leemtes in ons kennis van hierdie variëteit(e) van Afrikaans te vul, is ook gebruik gemaak van bronne waarin die taalgebruik van voormalige Khoisprekers gesimuleer word deur andere (byvoorbeeld Hendrik Kok deur C.E. Boniface) of bronne met voormalige Khoisprekers as teikengroep (byvoorbeeld Afrikaanse tekste of teksgedeeltes - in teenstelling met Nederlands - uit die Genadendalsfeer). Die bronne is ook baie heterogeen van register, en wissel van die amptelike korrespondensie van die Namaleier Hendrik Witbooi tot die klugspel "Kaatje Kekkelbek" met kodewisseling tussen Afrikaans en Engels. Die bronne wissel ook van prosa tot dramatiese dialoog, en strek vanaf aanhalings uit die laat $17 \mathrm{de}$, vroeg $18 \mathrm{de}$ eeu tot onderhoude uit die laat 20ste eeu. As 'n tipe kontrole of vergelykingsbasis is 'n korpus

\footnotetext{
${ }^{2}$ Vgl. Links (1989:75-76) se opmerkings oor die "oormatige gebruik" van en, nou en toe; hy beskryf woorde soos en en toe as "'n stoplap in die spreektaal" en nou as 'n "bindwoordjie".
} 
spontaan gesproke taal van sprekers van die standaardvariëteit van Afrikaans uit die tagtigerjare gebruik (die "Spontane Korpus"), asook die drama Kanna hy ko' hys toe van die Kaapse dramaturg Adam Small.

Aspekte wat ondersoek is:

- abolute frekwensieverskille van partikels wat deur die Khoigroep in vergelyking met kontrolegroepe gebruik is of word;

- verskille tussen die Khoigroep en die kontrolemateriaal wat betref die relatiewe gebruiksfrekwensie van Nederlandsverwante en tipies Afrikaanse partikels;

- die gebruik van kollokasies van partikels, bv. mos, nou, maar, in verskillende groepe;

- die gebruik van partikels in die semantiese veld van immers, mos, tog en ja;

- die oorgang van daarom na darem;

- die ontwikkeling van sommer uit zo maar, en

- enkele ander partikels by wyse van kort opmerkings.

\section{Keuse van bronne}

Die bronne waarop hierdie ondersoek gebaseer is, is heterogeen van aard en bestaan uit aanhalings, briewe, onderhoude, dramas, korpusse, dialooguittreksels, tydskrifrubrieke en gesprekopnames. Die volgende bronne is ondersoek:

1) Uitsprake van Khoi-Khoin is opgeteken deur die Nederlander Willem ten Rhyne wat die Kaap in 1673 aandoen en die Duitser Peter Kolbe (of Kolb) wat van 1705 tot 1713 aan die Kaap vertoef (vgl. Raidt 1991:124-126). In eersgenoemde aanhaling word mashy (= maskie) gebruik, in laasgenoemde verskeie kere ja as partikel.

2) Twee briewe wat in 1800 deur Carolus en Jan Bastert aan die Nederlandsch Zendeling-Genootschap geskryf is, gee ons volgens Den Besten (2005) 'n blik op die "Khoekhoe-Afrikaans" van rondom die eeuwisseling. Tog (een maal toch gespel) speel 'n relatief groot rol, met 10 gebruiksgevalle. Ander partikels is maar (2x), zo(o) maar $(2 \mathrm{x})$ en eens ( $2 \mathrm{x}$, met modale waarde soos in Nederlands) en ja (1x). Immers (1x) stem ooreen met Ndl./Afr. immers eerder as mos.

3) C.E. Boniface, redakteur van die Oosgrensblad De Zuid-Afrikaan, publiseer in 1830 sy vrye weergawe van 'n onderhoud met 'n Khoi-Khoi, Hendrik Kok, tydens dié se besoek aan die redaksiekantoor (Nienaber 1971:36-49). Ofskoon dit nie hier om 'n egte Khoispreker gaan nie, is die onderhoude in die styl van 'n lewendige gesprek oor 'n aktuele onderwerp. Nienaber (1971:44) wys op "die oorvloedige gebruik van modale en ander stemmingswoordjies". Kok bedien hom in die onderhoude van die volgende: mus/ mos (19x), toch (6x), maar (5x), neh(n) (5x), zoo maar (3x), regt (2x), maskie $(2 \mathrm{x})$, dan $(2 \mathrm{x})$, voor vas $(2 \mathrm{x})$, altedanag/ al te danage $(2 \mathrm{x})$, en elk van die volgende een maal: regreg, alle mense, juis, nou, eers.

4) Nienaber (1971:47-51) haal 'n brief aan wat in 1830 onder die skuilnaam van "een Verdrukte Grikwa" in The South African Commercial Advertiser verskyn, en merk onder meer op die skrywer "gee voor dat hy 'n Griekwa is" en dat daar "niks (is) wat sy Afrikaans 'n duidelike Griekwa-kleur gee soos ons dit later leer ken nie, behalwe 
miskien zoma (ons somaar)". Die volgende partikels kom voor: dan (5x), tog (6x), (net) maar (2x), zo marl zoma $(2 \mathrm{x})$ en een maal daarom en regt.

5) A.G. Bain en F. Rex se revue in 'n mengsel van (vroeë) Afrikaans en Engels, met die titel "Kaatje Kekkelbek; or Life among the Hottentots", word in 1838 in Grahamstad opgevoer (vgl. Nienaber 1971:67-75). Die volgende partikels word gebruik: $r e g(t)$ $(3 \mathrm{x})$, rasnawel $(2 \mathrm{x})$, juist $(2 \mathrm{x})(=$ Eng. just) en een maal maskie en toch.

6) Van ene Sabiena Zeekoeygat ${ }^{3}$ verskyn daar in 1846 'n brief in Het Kaapsche Grensblad (Nienaber 1971:118). Ons vind hier toch/tog (5x) - een maal in foei tog -, mos $(2 \mathrm{x})$, regte $(2 \mathrm{x})$ en kasta $(1 \mathrm{x})$.

7) In J.J. de Kock se "Tooneelen uit het Politie Hof" (soos aangehaal deur Nienaber 1971:216) word 'n dialoog in 1860 tussen 'n magistraat en 'n Khoikhoi, ene Daantje, weergegee; Daantje antwoord onder meer: Toe maar, maak gou [met die vonnis], ... een mens is mos een mens; en Nou, das goed, laat mijn dan maar afklop.

8) In De Bode van Genadendal, 'n "Godsdienstig Maandblad voor Christelijke Huisgezinnen en anderen" (oorspronklik gerig op sending onder die Khoi-Khoin) van September 1864 (p.35) verskyn onder die opskrif "Een gesprek" 'n dialoog met 'n sterk Afrikaanse inslag tussen 'n boer en sy bejaarde werknemer, waarin die waarde van onderwys beredeneer word. Partikels wat gebruik word, is onder meer maar (10x), moes ('mos', 10x), daarom (5x) toch (3x), zoomaar (3x) en zeker (2x). In De Bode van Mei 1873 verskyn daar 'n aflewering van 'n nuusrubriek met die opskrif "Brief van oom Louw Gezels". Partikels wat voorkom, is onder meer daarom (6x), moes ('mos', 5x), maar ( $4 \mathrm{x})$, toch (4x), regt(e) (3x) en $n u(2 \mathrm{x})$.

9) Benigna van Groenekloof of Mamre - Een verhaal voor de Christen Kleurlingen van Zuid-Afrika verskyn in 1873 in Genadendal uit die pen van die Morawiese sendelingonderwyser Herman Benno Marx (vgl. Koch 2006) wat te Genadendal werksaam was. Die dialoog, omraam deur 'n Nederlandse teks, is in wisselende grade "Afrikaans". Aangesien die sending op Genadendal hoofsaaklik op die Khoi-Khoin gerig was, kan aangeneem word dat Marx se dialoog 'n poging is om die taalgebruik van (gewese) Khoisprekers van Afrikaans weer te gee. Die volgende word in die dialooggedeeltes gevind: toch (21x), maar (12x), zoo/soo maar (4x), mos (4x), daarom (4x), reg(t) (2x) en een maal elk: misschien, waarlijk en juis.

10) Uit Die Dagboek van Hendrik Witbooi (1929:1-95) is die eerste 30 briewe ondersoek. Hierdie materiaal, uit die tydperk 1884-1890, is wel regstreeks van 'n Khoisprekende afkomstig, maar is van 'n formele aard (amptelike briewe) en neig sterk na Nederlands. Die volgende modale partikels kom voor: toch (34x), maar (7x), regte $x$ reg(t) (3x), misschien/mieschien ( $2 \mathrm{x})$ en een maal eigenlijke.

11) Transkripsies van onderhoude wat in die tagtigerjare met Griekwas gevoer is as deel van 'n navorsingsprojek onder leiding van M.C.J. van Rensburg (1984, band II, deel 2) maak die grootste gedeelte van die materiaal afkomstig van (gewese) Khoisprekers

\footnotetext{
${ }^{3}$ Sy beskou haarself as een van die Khoi-Khoin (Nienaber 1971:118-119).
} 
uit. In die bestek van 228 bladsye, wat die taalgebruik van minstens agt persone verteenwoordig, kom die volgende voor: mos (117x), somme $(r) /$ soemer $(86 \mathrm{x})$, ma $(a) r /$ ma $(41 \mathrm{x})$, darem/daem, ens. $(21 \mathrm{x})$, eintlik, ens. (16x), ree $(d) s(9 \mathrm{x})$, rêrig/rêrag $(6 \mathrm{x})$, ('n) bietjie (3x), dalk (3x), seker (3x), dan (2x), maskien/miskien (2x), net-nou (2x), nogal (2x) en 'n enkele maal kamma, tog, toemar en sekerlik.

12) In Links (1989:89-105) is ses getranskribeerde onderhoude met "gekleurde" mans en vroue van tussen 76 en 92 jaar van "Kharkams en omliggende nedersettings" (vgl. Links 1989:1) in Namakwaland opgeneem. Die volgende partikels kom in die respondente se antwoorde na vore: mos (119x), maar (20x), darem (7x), kamma (4x), tog $(2 \mathrm{x})$, sommer $(2 \mathrm{x})$ en een maal eintlik, glo, seker en hoeka.

13) As kontrole word gebruik gemaak van die sogenaamde Spontane Korpus, een van drie korpusse waarop die "Frekwensiebepaling van die kernwoordeskat en sekere basiese strukture van die Afrikaanse spreektaal" (Kroes 1982), berus. Aangesien die sprekers tipiese gebruikers van Standaardafrikaans is en ten tyde van die opnames onbewus van die opname was, is die teks besonder geskik as kontrole, ook omdat die opnames ongeveer in dieselfde tydperk as dié van (11) gemaak is. Die volgende kom voor: maar $(157 \mathrm{x})$, mos $(108 \mathrm{x})$, sommer $(63 \mathrm{x})$, eintlik $(57 \mathrm{x})$, darem $(54 \mathrm{x})$, tog $(30 \mathrm{x})$, rêrig, ens. (20x), juis (14x), miskien $(3 \mathrm{x})$ en reeds $(1 \mathrm{x})$.

14) Om die vergelykingsbasis te verbreed, word Adam Smal (1989) se drama Kanna hy $\boldsymbol{k} \hat{\boldsymbol{o}}$ hystoe (in 1965 vir die eerste maal uitgegee) ontleed, as voorbeeld van die variëteit wat as "Kaapse Afrikaans" getipeer kan word. Die teks het die voordeel dat dit as drama die styl van die gesproke taal benader, maar daar moet rekening gehou word met die feit dat dit 'n weergawe is van een taalgebruiker, naamlik die skrywer, se idiolek en die algemene stemming wat deur die drama weerspieël word. Let daarop dat dit nie die doel van hierdie studie is om 'n beeld te gee van "Kaapse Afrikaans" nie. Die volgende is gevind: darem (33x), mos (20x), maar (20x), soemaar $(7 \mathrm{x})$, regtig/ regtag (4x), simplie (2x), sieker, kamma en even.

\section{Gebruiksfrekwensie van partikels in die grootste bronne}

Die gebruiksfrekwensies (tokens) van die modale partikels in die grootste bronne wat die meeste voorgekom het, word in Tabel 1 uiteengesit.

Tabel 1. Gebruiksfrekwensie van partikels in die grootste bronne

\begin{tabular}{|c|c|c|c|c|c|c|c|}
\hline Tekste & \begin{tabular}{|l}
3. \\
Kok
\end{tabular} & $\begin{array}{l}9 . \\
\text { Benigna }\end{array}$ & $\begin{array}{l}10 . \\
\text { Witbooi }\end{array}$ & $\begin{array}{l}11 . \\
\text { Griekwas }\end{array}$ & $\begin{array}{l}12 . \\
\text { Kharkams }\end{array}$ & $\begin{array}{l}13 . \\
\text { SK } \\
\text { (kontrole) }\end{array}$ & $\begin{array}{l}14 . \\
\text { Kanna }\end{array}$ \\
\hline $\begin{array}{l}\text { darem,daem, } \\
\text { daarom, ens. }\end{array}$ & $\begin{array}{l}-\% \\
-\quad 0\end{array}$ & $\begin{array}{ll}4 & \% \\
& 8\end{array}$ & $\begin{array}{c}\% \\
0\end{array}$ & $\begin{array}{ll}21 & \% \\
& 7\end{array}$ & 7 & $\begin{array}{ll}54 & \% \\
& 11\end{array}$ & $\begin{array}{rr}33 & \% \\
& 39\end{array}$ \\
\hline $\begin{array}{l}\text { ein(t)lik, entlik, } \\
\text { een }(t) l i k, \text { ens. }\end{array}$ & 0 & 0 & 1 & 16 & 1 & 57 & 0 \\
\hline maar, mar (bw) & 14 & $\begin{array}{ll}12 & \\
& 26\end{array}$ & 16 & 41 & 20 & $\begin{array}{l}157 \\
32\end{array}$ & 20 \\
\hline
\end{tabular}




\begin{tabular}{|c|c|c|c|c|c|c|c|}
\hline mos, mus, mәs & $\begin{array}{ll}19 & \\
& 53\end{array}$ & 4 & 0 & $\begin{array}{ll}117 & \\
& 41\end{array}$ & $\begin{array}{ll}119 & \\
& 79\end{array}$ & $\begin{array}{ll}108 & \\
& \end{array}$ & $\begin{array}{ll}20 & \\
& 24\end{array}$ \\
\hline reg $(t)$, regte & 2 & 2 & 3 & 0 & 0 & 0 & 0 \\
\hline rêrig, regtig & 1 & 0 & 0 & 6 & 0 & 20 & 4 \\
\hline sommer, soo maar & 3 & 4 & 0 & 86 & 2 & 63 & 7 \\
\hline tog, toch & $\begin{array}{ll}6 & \\
& 17\end{array}$ & $\begin{array}{ll}21 & \\
& 45\end{array}$ & $\begin{array}{ll}34 & \\
& 76\end{array}$ & 1 & 2 & 30 & 0 \\
\hline $\mathrm{N}=$ & 36 & 47 & 45 & 288 & 151 & 489 & 84 \\
\hline
\end{tabular}

Die gebruiksfrekwensies in Tabel 1 kan ook soos volg voorgestel word:

(3) Kok: $\operatorname{mos}(43 \%)>\operatorname{tog}(17 \%)>\operatorname{maar}(14 \%)>\operatorname{sommer}(8 \%)>\operatorname{reg}(6 \%)$

(9) Benigna: $\operatorname{tog}(45 \%)>$ maar $(26 \%)>$ darem $/$ mos/sommer (elk $8 \%)$

(10) Witbooi: $\operatorname{tog}(76 \%)>\operatorname{maar}(16 \%)>\operatorname{reg}(7 \%)$

(11) Griekwas: $\operatorname{mos}(41 \%)>\operatorname{sommer}(30 \%)>$ maar $(14 \%)>$ darem $(7 \%)>$ eintlik $(6 \%)$

(12) Kharkams: mos $(79 \%)>$ maar $(13 \%)>$ darem $(5 \%)$

(13) SK: $\operatorname{maar}(32 \%)>\operatorname{mos}(22 \%)>\operatorname{sommer}(13 \%)>\operatorname{eintlik}(12 \%)>$ darem $(11 \%)>$ $\operatorname{tog}(6 \%)$

(14) Kanna: darem $(39 \%)>$ maar/ mos (elk $24 \%)>\operatorname{sommer}(8 \%)>$ rêrig $(5 \%)$

Die volgende kan waargeneem word:

- Tog staan relatief sterk by Kok (3), Benigna (9) en Witbooi (10) - al drie oorredende tekste en met Nederlandse invloed, laasgenoemde merendeels amptelike korrespondensie; elders speel tog 'n geringe rol.

- Mos se frekwensie is bokant 20\% in al die grootste bronne, behalwe Witbooi (10) en Benigna (9) - dus 'n duidelike spreektaalkenmerk en in (3), (11) en (12) selfs die partikel met die hoogste frekwensie. Laasgenoemde drie bronne is onderhoude, waarin met name die uitruil van inligting belangrik is.

- Maar kom in al die bronne voor.

- Darem oortref ander partikels in Kanna (14), maar is skaars elders.

\section{Nederlandsverwante teenoor tipies Afrikaanse partikels}

Afrikaanse modale partikels kan onderskei word in dié wat feitlik dieselfde as in Nederlands gebruik word, ander wat verwantskap met Nederlands toon maar 'n eie ontwikkeling in Afrikaans ondergaan het en enkele tussengevalle. Die vraag kan gestel word of sprekers met 'n Khoi-agtergrond 'n groter voorkeur vir die tipies Afrikaanse partikels sou toon. Om so na as moontlik aan die gesproke taal te bly, is net van dialoogbronne gebruik gemaak, te wete (3), (9), (11) en (12); ook die kontrolekorpus (13) en Kanna (14) bestaan uit dialoog. 
As Nederlandsverwante partikels is gekies eintlik (Ndl. eigenlijk), ook weergegee/ uitgespreek as einlik, eentlik of eenlik; die bywoord maar (Ndl. maar), ook mar, en tog (Ndl. toch). As tipies Afrikaanse partikels is gekies darem (uit die Ndl./Afr. voegwoordelike bywoord daarom), ook weergegee/uitgespreek as daem, maar soms ook daarom (telkens in modale funksie); mos (uit Ndl./Afr. immers), ook mus, en rêrig (uit Ndl. recht, Afr. reg, met reduplikasie, vgl. Conradie 2011), ook regtig en reg-reg. Sommer (uit Ndl. zo maar) is buite rekening gelaat omdat dit in 'n hoë mate met die Nederlands ooreenstem, nou weens die uitermate hoë frekwensie daarvan en by gebrek aan 'n vergelykende studie met Nederlands, en ander partikels onder meer vanweë lae gebruiksfrekwensie.

Tabel 2. Nederlandsverwante teenoor tipies Afrikaanse modale partikels

\begin{tabular}{|c|c|c|c|c|c|c|}
\hline Tekste & $\begin{array}{l}3 . \\
\text { Kok }\end{array}$ & $\begin{array}{l}9 . \\
\text { Benigna }\end{array}$ & $\begin{array}{l}11 . \\
\text { Griekwas }\end{array}$ & $\begin{array}{l}12 . \\
\text { Kharkams }\end{array}$ & $\begin{array}{l}13 . \\
\text { SK } \\
\text { (kontrole) }\end{array}$ & $\begin{array}{l}14 . \\
\text { Kanna }\end{array}$ \\
\hline $\begin{array}{l}\text { eintlik, maar, tog } \\
+ \text { wisselvorme }\end{array}$ & $\begin{array}{rr}11 & \% \\
& 35 \\
\end{array}$ & $\begin{array}{r}33 \\
80 \\
\end{array}$ & $\begin{array}{ll}121 & \% \\
& 46 \\
\end{array}$ & $\begin{array}{rr}23 & \% \\
& 15 \\
\end{array}$ & $\begin{array}{c}244 \% \\
57 \\
\end{array}$ & $\begin{array}{rr}20 & \% \\
& 26 \\
\end{array}$ \\
\hline $\begin{array}{l}\text { darem, mos, } \\
\text { rêrig } \\
\text { wisselvorme }\end{array}$ & 20 & 8 & 144 & 126 & $\begin{array}{ll}182 & \\
& 43\end{array}$ & 57 \\
\hline $\mathrm{N}=$ & 31 & 41 & 265 & 149 & 426 & 77 \\
\hline
\end{tabular}

In bronne (3), (11) en (12) - al drie onderhoude met persone met 'n Khoi-agtergrond oorheers die gebruik van "tipies Afrikaanse" partikels; Kanna (14) sluit hierby aan. Hierteenoor toon die kontrolekorpus (13) 'n voorkeur vir die "Nederlandsverwante" partikels; die dialoog in Benigna - omraam deur 'n Nederlandse teks en nie in die onderhoudregister nie - sluit egter by laasgenoemde aan. Hierdie verdeling maak dit waarskynlik dat die gebruik van tipies Afrikaanse partikels met 'n Khoi-agtergrond saamhang; die gebruik daarvan in Kanna suggereer dat 'n voorkeur vir die Afrikaanse partikels ook in ander variëteite kan/kon voorkom.

\section{Kollokasies van modale partikels}

Die voorkoms van kollokasies - in casu reekse van twee of meer gebruiksgevalle - van modale partikels in tekste is ' $n$ aanduiding daarvan dat hulle gebruik goed ingeburger is by ' $n$ bepaalde groep; in Nederlands is byvoorbeeld moontlik:

Geef die boeken dan nou toch maar eens even hier. (Haeseryn, Romijn, Geerts, De Rooij en Van den Toorn 1997:1349).

'n Uitgebreide eksemplaar uit Benigna (9, p.61) lui,

“Ach," zeide zij, "als hij toch nou ook maar hier naar toe wil trek."

In die Griekwakorpus (11) tref ons kollokasies aan soos,

toe kom ik nou weer darem ok nog so by met die pratery dan sal ek nou maar sommer vir hom mit die vier brand Toe's ek nog mar sommer so opgeskoot. 
As die Griekwa-onderhoude (11, asook 'n verdere aantal onderhoude) as verteenwoordigend van die Khoigroep beskou en met die kollokasies in die kontrolekorpus (13) vergelyk word, is dit duidelik dat albei groepe ruimskoots van kollokasies gebruik maak. Veral mos en maaren dikwels albei saam - maak deel uit van die kollokasies. Uit 'n vergelyking van die getalle gebruiksgevalle (tokens) blyk egter dat Griekwa-Afrikaans 'n voorkeur het vir mos as kollokasieonderdeel, en die kontrolekorpus vir maar. Hoogs frekwente kollokasies wat opval, is 38 gevalle van mos nou in die geval van Griekwa-Afrikaans (slegs 5x in SK), soos in

\section{die vijool kom mos nou later eers yt}

en - in soverre net en nou ook as modaal beskou kan word - maar net (23x in (13); 1x in (11)) en nou maar (35x in (13); $2 \mathrm{x}$ in (11)), soos in

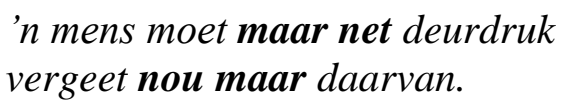

Die hoë frekwensie van mos nou by die meeste Griekwa-ondervraagdes kan moontlik toegeskryf word aan die onderhoudsituasie, waarin uiteraard inligting gevra word en die ondervraagde wil verduidelik sonder dat die ondervraer aansien inboet. Waar die onderhoudvoerder 'n man - bowendien uit 'n ander bevolkingsgroep - is wat 'n vrou uitvra oor hoe 'n jong Khoi-Khoivrou tydens inisiasie begelei word, verg die situasie geduldige toeligting deur die begeleidster (vgl. (11)):
... as hulle mos nou groot word ...
dan vat ek haar mos nou water toe ...
Die waterslang is mos eintlik nou daar by die rivier.
dis mos nou(,) dit meen dis mos nou die grootmeisie(, ) bas
daai tyd mag hy [= sy] mos nie met hulle praat nie
hulle sing mos nou so soos ek daar dans

\section{Die verhouding immers, mos, tog en ja}

Volgens Conradie (1995:51) "steun mos-uitings sterk op, of suggereer hulle gemeenskaplike faktore soos kennis, insig, solidariteit, gesagstrukture, morele kodes - wat die spreker met andere (die aangesprokenes óf derdes) deel". Mos kan enersyds verskonend - dit wil sê as beleefdheidsvorm - gebruik word in geval die aangesprokene reeds oor die meegedeelde inligting beskik, maar andersyds, in die redenerende styl, om inligting as argument of getuienis aan te bied. Hendrik Kok (3) gebruik mos/mus by uitstek om sy argumente krag te gee, bv.

\section{Ach, maar het is mos nie zoo, sjeur! waarom moet ik dan leugens vertel?}

In (10) word 'n dialoog tussen 'n magistraat en 'n Khoi-Khoi, ene Daantje, weergegee; Daantje antwoord onder meer:

Toe maar, maak gou [met die vonnis], ... een mens is mos een mens.

Toch maak driekwart van die partikels uit wat Witbooi (10) gebruik. Hy gebruik hulle in 'n verskeidenheid kontekste, en met uiteenlopende pragmatiese funksies en emotiewe waardes, bv. 
zoo moet u toch uwe best doen (vriendelike versoek)
en neem toch niet aanstoot (beleefde versoek)
bid tot God ernstelyk dat God toch ware vrede ... (smeekbede)
wanneer zal myne beesten toch geld hebben (versugting)
het zal U toch eindelijk zwaarlyk berouwen (dreigement)
en toch geen kogel raakte hem aan (teen verwagting in)
wat ben ik toch verbaas en verschrik geworden (uiting van verbasing)

Ook in "Kaatje Kekkelbek" (5) hoor ons:

Regt, jong! I wish toch dat de Mist-in-wary Syety would send me to England ...

$J a$ kom as sintakties geïntegreerde partikel $^{4}$ (dus nie as 'n soort losstaande tussenwerpsel vergesel van fonologiese breuke of aan die begin en einde van klouse nie), in die oudste aanhalings van Khoisprekers se taal voor, byvoorbeeld in aanhalings vroeg in die $18 \mathrm{de}$ eeu deur die Duitser Peter Kolbe. Hesseling (1923:53) haal uit die Kaapse stukke 'n insident aan waarin 'n slaaf in Kaapse Kreool-Portugees "Jacob ja morree" uitroep, "dat wil zeggen Jacob reeds sterv(en), voor: Jacob is dood", en wys daarop dat die verlede tyd in Maleis-Portugees op dieselfde wyse gevorm word. Den Besten (Van der Wouden 2012:282) gee ook, na aanleiding hiervan, 'already' aan as die betekenis van ja.

Hierdie gebruik het egter ook in vroeër Nederlands voorgekom en bestaan steeds in moderne Hoogduits. Aangesien ja as modale partikel in dieselfde semantiese veld val as immers, mos en tog, waarvan veral die laaste twee 'n hoë gebruiksfrekwensie in die bronne van (gewese) Khoisprekers het, is dit goed moontlik dat mos en tog diachroniese "opvolgers" van die japartikel is. Die moontlikheid moet dan ook ondersoek word of $j a$ ook 'n Khoi-oorsprong kan hê, byvoorbeeld as leenvertaling onder Nederlandse invloed (of onder die invloed van Duitsers se weergawe van Khoi).

Die volgende aanhalings is uit Kolbe (1727), die Nederlandse vertaling van die Duitse oorspronklike werk van 1719 (vgl. ook Franken (1953:92-93) en Raidt (1991:124-126)). Net die relevante gedeeltes word hier aangehaal en elke $j a$ word afsonderlik genommer. 'n KhoiKhoi het sy werkgewer, Jacob van der Heyden (deur almal aangespreek as Kobes), beloof om by hom te bly tot hy sy plaas afbetaal het, maar word toe hardhandig deur Van der Heyden behandel, waarop die Khoi-Khoi hom aan sy belofte herinner maar ook dreig om weg te loop (Kolbe 1727(I):121-122):

Kobes ik jou ja ${ }_{1}$ 'k hemme versproken', ik zoo lang zal by u blyven, tot jou Husing de dubbeltjes betaalt hemme, gy 'k hemme een oorfyg gemme, is dat braa? wagt om als gy de dubbeltjes betaalt hemme, $\underline{i k j a}$ istrakjes voort lopum zoo.

Kolbe vertaal die onderstreepte gedeeltes as "Jakob ik heb u belooft" en "past maar op, zoo dra als gy het geld zult hebben betaalt, zal ik weglopen". Aangesien die eerste sinsnede gedeelde kennis (naamlik die belofte) na vore haal, kan $j a_{1}$ goedskiks 'mos' of 'tog' beteken. In die konteks van die dreigement met strakjes 'oor 'n kort rukkie', kan $j a_{2}$ emfaties wees, en

\footnotetext{
${ }^{4}$ Abraham (1989) wys daarop dat modale partikels veral in die middelveld van tale met 'n SOV-struktuur (globaal onderwerp - voorwerp/ander materiaal - werkwoorde) ontwikkel; Khoi het inderdaad 'n SOV-struktuur. 5 'n Germanisme vir beloven.
} 
die sinsnede moontlik iets beteken soos "... sodra u die geld betaal het, gee ek beslis dadelik pad". Na 'n militêre onderonsie, sê die kaptein van die "Chamtouers" (Kolbe 1727(I):477) "in gebroken Hollandsch":

Ons denkum, ons altyd Baas, maar ons ja $\mathbf{3}_{3}$ zienom, Duitsman meer Baas,

wat Kolbe weergee as: 'Wy meenden, dat wy altyd meester waren maar nu zien wy, dat de Duitschers ons meester zyn.' $J a_{3}$, hier met $n u$ weergegee, kan in die konteks resultatief wees en 'immers' of 'tog' weergee. In reaksie op 'n stelling deur Kolbe, kry hy die volgende antwoord (Kolbe 1727(I):491):

\section{Duitsman ja $a_{4}$ musku slim, ons al te maal verraden,}

wat hy weergee as: "de Duitschers of Europeanen zyn ons al te sno ${ }^{6}$, zy zullen onzen gantschen handel verraden”. Musku kan op maskie of selfs moetoe (Port. muito) 'baie' dui. $J a_{4}$ is moontlik 'n fokuspartikel wat die klem op slim laat val.

Nadat die skrywer demonstreer dat 'n mens brandewyn wat pas gebrand het, kan drink, skreeu die toeskouers (Kolbe 1727(I):526):

Die man toverman, die man ja ${ }_{5}$ tover makum zoo.

Hulle wil egter nie glo dat dit moontlik is nie, en sê:

Gy ons immers dood makum, als ons die Goeds zuipen.

$J a_{5}$ tree in 'n kousatiewe konstruksie op (Die man is 'n towenaar, want hy toor) en kan moontlik 'immers' beteken. Immers word dan direk daarna in dieselfde betekenis gebruik: "As ons die goed drink, dan maak u ons immers dood." 'n Vrou laat 'n man hom met blou vitrioel insmeer om 'n siekte te genees, maar dit begin "elendig te byten" en hy skreeu "erbarmlyk" en sê (Kolbe 1727(I):528):

Ey Vrouw die Tovergoeds ja 6 zoo bytum, ons ik ka me niet verdragen.

$J a_{6}$ is hier moontlik 'n graadwoord ('erg') of uitroep/kragwoord. Waar hierdie insident in Deel II hervertel word (Kolbe 1727(II):163), kry ons 'n indruk van die illokusionêre krag van $j a_{6}$ :

Vrouw die Tovergoeds bytum als de Duivel, wat makum zoo?

Uiteindelik moet die man erken dat die "toorgoed" help, en hy sê onder meer (Kolbe 1727(I):528):

Ons Tovermanns... kame niet helpen, maar die Duits Tovervrouw $\mathbf{j a}_{7} \underline{\mathrm{bra}},{ }^{7}$ die kame helpe.

\footnotetext{
${ }^{6}$ Moontlik van snood, wat 'slecht, boos, misdadig' of 'schrander' kon beteken (VD).

${ }^{7}$ Roberge (2002a:94) gee die onderstreepte gedeelte weer as: "but the Dutch medicine woman [is] indeed good", d.w.s. ja met 'indeed'.
} 
$J a_{7}$ is hier moontlik 'n fokuspartikel by bra, 'n verkorte vorm van braaf, onder meer 'flink, eerbaar' en 'n graadwoord (VD). $J a$ word ook in die volgende in samehang met braaf (hier in die sin van '(beslis) goed, effektief') gebruik, maar dan handel dit oor die medisyne self (boegoe en ander kruie) (Kolbe 1727(II):162), byvoorbeeld, as dit help:

Die Tovergoeds ja $a_{8}$ braaf.

As dit nie help nie, moet die pasiënt hoor (ibid.):

Wagtum, die Tovergoeds niet sterk genoeg, ons ja $\boldsymbol{a}_{9}$ een ander makum, die ja $\mathbf{a}_{10}$ braaf sterk.

$J a_{10}$ is weer 'n fokuspartikel; $j a_{9}$ kan 'immers' wees (kousatief), of miskien 'dan', wat dui op temporele opeenvolging. $J a$ benader 'mos', waar een van die "Damaquas", op 'n onsensitiewe vraag oor hulle seksuele gewoontes, gebelgd antwoord (Kolbe 1727(II):30):

Die Volk, ja $a_{11}$ denkum ons beesten; ha! ... ons niet zoo, want het deugum niet.

('Julle mense dink mos ons is diere ...'). Op 'n vraag oor wat lastige bloedsuiers te beurt val, is die antwoord (Kolbe 1727(II):66):

Die goeds ons ja $a_{12}$ beitum, en ons bloed op vretum; waar om ons die goeds niet weder beitum en op vretum.

$J a$ sou hier 'immers' of 'mos' kon wees.

Moontlike semantiese waardes van die sintakties geïntegreerde $j a$ in uitsprake van die KhoiKhoin soos deur Kolbe (1727) weergegee, is dus: 'immers', 'mos' of 'tog' ( $j a_{1,3,5,9,11}$ en 12 ), as fokuspartikel, emfaties, 'beslis' ( $\mathrm{j}_{2,4,7,8}$ en ${ }_{10}$ ) en as graad- of kragwoord $\left(j a_{6}\right)$. Kyk ons na $j a$ as afkomstig uit Kreools-Portugees in die betekenis 'reeds' of 'already' (vgl. hierbo), dan lyk dit asof slegs $j a_{1}$ en $j a_{3}$ moontlik hierdie betekenis kon hê, tensy aangeneem moet word dat hierdie temporele $j a$ in die Portugees van die slawe ook reeds modale waardes aangeneem het (vgl. Afr. reeds 'juis' in Ek sê reeds vir hom dis gevaarlik daar.) Dit sou die moontlikheid open van 'n konvergente ontwikkeling in Khoi- en slawe-Afrikaans. Ja het in geen geval 'n duidelike verledetydsfunksie nie: $j a_{1}$ staan in 'n sin wat reeds die verlede tyd deur middel van hulpwerkwoord en voltooide deelwoord aandui, $j a_{2}$ in 'n $\sin$ in die toekomende tyd.

Die WNT (onder ja) wys daarop dat ja soms "in het zinsverband ingevoegd" word in die betekenis 'immers, toch, voorwaar' - 'n gebruik wat in sommige dialekte, met name Gronings, "nog zeer gewoon" is: Dat spreekt toch ja van zelf. Da's ja mooi. Ook VD dui ja in dat spreekt toch ja van zelf! as 'immers' in gewestelike gebruik aan. Ofskoon hierdie sintakties geïntegreerde gebruik van ja anders as in die geval van Duits nie meer algemene Nederlands is nie, kon dit tog in vroeëre eeue 'n rol aan die Kaap gespeel het.

$J a$ kom ook in 1800 - dus byna 'n eeu later - in 'n brief van ene Carolus Bastert (2) voor; 'voorwaar' of 'tog' is hier 'n moontlikheid, maar hier moontlik onder die invloed van die 
soortgelyke gebruik van ja in Duits (voorbeeld uit Den Besten 2005:27), bv. as toegewing (er mag ja recht haben: he may well be right):

$i k$ wou het amper niet gelooven, maar nouw voel ik dat ja mijn sonden meer

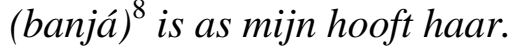

Ofskoon hierdie gebruik van 'n sintakties geïntegreerde ja nie deel uitmaak van latere Afrikaans nie en die presiese betekenis in die gebrekkige kontekste nie goed agterhaalbaar is nie, kan die vraag tog gestel word of die hoë frekwensie van tog en veral mos in latere taalgebruik nie die funksie van sinsinterne $j a$ oorgeneem het nie. In terme van vertaalekwivalente in 'n aantal woordeboeke kan die gebruiksverhoudings tussen 'n aantal modale partikels soos volg gekonstrueer word:

\section{Nederlands}

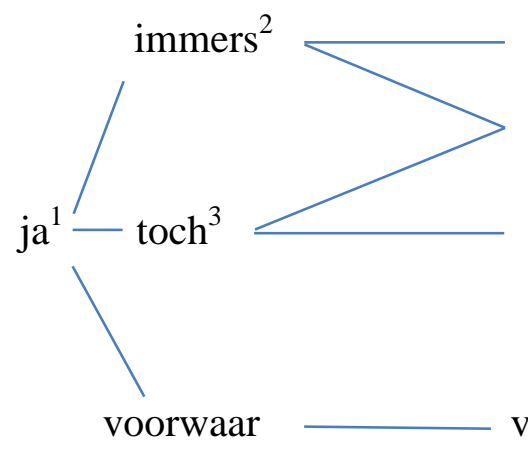

Afrikaans

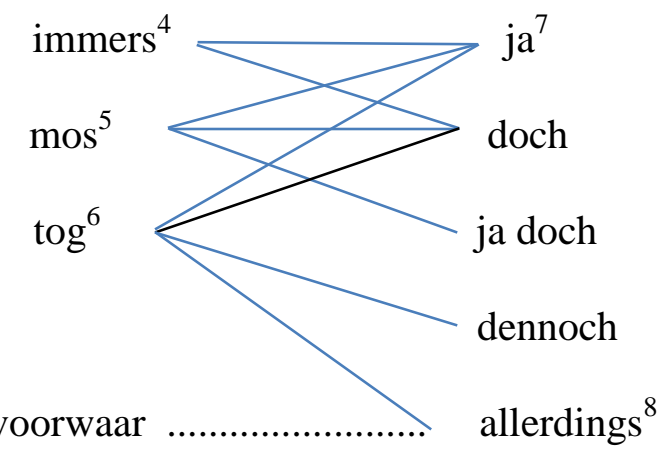

Figuur 1. Vertaalekwivalente van 'n aantal partikels en bywoorde

1) Sintakties geïntegreerde $j a$ is volgens WNT in die betekenisse 'immers, toch, voorwaar' in sommige dialekte, o.m. Gronings, "nog zeer gewoon", vgl. Dat spreekt toch ja van zelf.

2) Ndl. immers korreleer volgens GWAN met sowel immers as mos in Afrikaans. ${ }^{9}$

3) Ndl. toch korreleer volgens GWAN met sowel tog as mos in Afrikaans, vgl. Ndl. dat kan toch niet?, Afr. dit kan tog/mos nie wees nie?

4) Afr. immers korreleer volgens WAD o.m. met ja en doch in Duits.

5) Afr. mos korreleer volgens WAD met ja doch in Duits, vgl. Ek het jou mos gesê: Ich habe es dir doch ${ }^{10}$ gesagt.

6) Afr. tog korreleer volgens WAD o.m. met doch, dennoch en allerdings in Duits.

7) Duits ja (sintakties geïntegreerd) korreleer volgens WAD met tog, immers en mos in Afrikaans (en word ook in die voorbeelde met wel en maar vertaal), vgl. es ist ja zu spät: dit is mos te laat.

8) Duits allerdings korreleer volgens WAD met sekerlik, stellig, ongetwyfeld, weliswaar en egter in Afrikaans.

Dat daar in Khoi ook ruimte vir 'n modale partikel soos $j a$ in die sintaktiese middelveld kon wees, blyk onder meer uit 'n aantal uittreksels uit 'n Bybelvertaling in Nama wat deur Planert

\footnotetext{
${ }^{8}$ Vir die hakies, vgl. Den Besten (2005:30).

${ }^{9}$ Die historiese verband tussen mos en immers aan die Kaap word uitvoerig bespreek deur Roberge (2002b).

${ }^{10}$ Die voorbeeld het egter net doch.
} 
(1905) as oefeningstukke aangebied en van 'n interliniêre vertaling in Duits voorsien word. NW verskaf vir Nama gum ... o, go ... o, go as (Duitse) ekwivalent: ja doch; Planert (1905:24) gee vir gum en wisselvorme 'ja, doch wohl' aan, Wallmann (1875) vir gum 'o, ja, freilich'. Die volgende interliniêre woordglosse by die Namavertaling in Planert (1905: 29-36), waarin Nama gum telkens as (Duits) $j a$ weergegee word, gee 'n aanduiding van die moontlike betekenis of funksie van gum in Nama:
a. $\quad$ Mein Vater du, sündigen ich tat dem Himmel gegenüber und dir vor. Und ich ja bin wert nicht ferner dein Sohn genannt zu werden (Luk. 15:19 en vgl. 21) [daarom, tog?]
b. Dein Bruder ja [immers, mos?] tat herkommen und er ja [daarom?] dein Vater gemästeten Kalb tat schlachten (Luk. 15:27)
c. Und du ja, dieser dein Sohn, (welcher) die Güter deine den Huren mit pflegte (zu) verbringen er (Luk. 15:30) [maar?]
d. Mein Sohn, du ja immerfort mir bei bist (Luk. 15:31) [mos, tog?]
e. $\quad$ Und es ja Jubel und Freude als zu sein ist wert, dieser dein Bruder tat tot sein und tat wieder leben (Luk. 15:32) [mos, $\operatorname{tog}^{11}$ ?]
f. Und er Abraham ihm zu sagte: Moses und die Propheten und sie sie ja haben (Luk. 16:29) [mos, tog?]
g. $\quad$ Moses und die Propheten und sie sie hören nicht wenn, dan sie ja auch glauben werden nicht (Luk.16:31) [mos, tog?]
h. $\quad$ Freund du, böse ich ja behandle dich nicht (Mat. 20:13) [mos, tog?]

Vgl. ook Luk. 16:29 en Mat. 20:7. Dit is opvallend dat die Griekse bronteks nêrens 'n liniêr ooreenstemmende Griekse woord bevat wat met Nama gum vertaal word nie. ${ }^{12}$ Dit wek die indruk dat so 'n sintakties gebonde partikel 'n bepaalde leemte gevul het. In enkele gevalle bevorder gum moontlik die kousale verband tusen proposisies $(\mathrm{a}, \mathrm{b})$ of druk dit 'n teenstelling uit (vgl. (c)); in meer gevalle (d-h) soek die spreker instemming by die aangesprokene en sou mos of tog vertaalekwivalente kon wees.

\section{Daarom en darem}

Darem, afkomstig uit Ndl./Afr. daarom, is ook 'n modale partikel wat betreklik dikwels voorkom: in $7 \%$ van die gevalle in (11), $5 \%$ in (12) en $8 \%$ in die dialoog in (9). Dit kom selfs meer in die kontrolekorpus (13) voor (11\%) en veel meer in Kanna (14) (39\%). Afr. darem het deur 'n proses van grammatikalisasie wat berus op toenemende subjektifisering uit die Ndl./Afr. voegwoordelike bywoord daarom ontwikkel tot 'n modale partikel wat in betekenis en vorm van daarom verskil. Terwyl daarom en darem as doeblette in die meeste tekste duidelik onderskei word, kry ons in die Genadendalse tekste, De Bode van Genadendal (8) en Benigna (9), 'n blik op 'n stadium van verandering waarin die skeidingsproses nog nie afgehandel was nie. Die spelvorm is in hierdie tekste steeds daarom.

Die volgende stappe kan in die subjektifiseringsproses onderskei word:

Daarom ${ }^{1}$ : Ndl./Afr. daarom 'om dié rede' dui hipotaktiese verband aan, met ander woorde verbind twee proposisies: Ik denk, daarom ben ik. - Ek dink, daarom is ek.

\footnotetext{
${ }^{11}$ Die Afrikaanse 1983-vertaling lui: "Maar ons kan tog (my kursivering) nie anders as om fees te vier en bly te wees nie."

${ }^{12}$ Met dank aan prof. Gert Steyn vir bevestiging hiervan.
} 
Daarom $^{2}$ : Ndl./Afr. daarom 'desondanks, in weerwil van' - nou met teenstelling tussen die "rede" en die wil/ besluit van die subjek; vergelyk:

(i) het mag niet, maar daarom doen ze het wel: desondanks (GK)

(ii) ik weet dat het niet goed is, maar ik kan het daarom niet laten: nochtans niet, inweerwil daarvan nog niet laten (VD, en vgl. WNT)

Vergelyk ook WAT: Hy is arm, maar daarom nog nie ongelukkig nie. Hoewel die motivering of rede steeds as verwysingspunt dien, is die sintaktiese skakelfunksie deur 'n ander voegwoord (maar in (i) en (ii) hierbo) oorgeneem; daarom kan in die middelveld voorkom, soos in (ii), en hoef nie vooropgestel te wees soos in (i) nie. Ontkenningsinne speel moontlik 'n brugrol, want die posisie van modale partikels is vóór die (eerste) ontkenning.

Darem $^{1}$ : Afr. darem ${ }^{13}$ 'tog, teen die verwagting in, minstens': darem verwys nou na 'n presupposisie, 'n onuitgesproke verwagting van die spreker, dus nie deel van 'n hipotaktiese verband nie.

(iii) Ons span het darem die paal gehaal.

Let op dat die realisering die verwagting oortref, die presupposisie ophef.

Darem $^{2}$ : Afr. darem 'regtig, werklik': darem het 'n fokuspartikel geword, wat die klem (ook fonologies) op 'n ander sinsdeel laat val:

(iv) Die weer lyk darem lélik/darem nie te lelik nie.

(v) Hy is darem 'n grapmaker soos min.

Darem se modale funksie het hiermee tot 'n blote diskoersfunksie (klem) veralgemeen. Die teenstelling met 'n verwagting is dus vervang deur 'n implisiete appél op die aangesprokene se oordeel. Hierdie darem is enigsins emotief.

In die volgende het daarom steeds 'n hipotaktiese funksie, met 'desondanks' of 'tog' as moontlike betekenis - dus daarom ${ }^{2}$.

En hij schrijft hem, dat in de Engelsche Kerk, al is dat niet den paus zijn kerk, daarom over de 100 leeraren zijn, die het Roomsche geloof hebben, maar die daarom nog bij een Evangeelsche kerk blijven. (uit "Brief van oom Louw Gezels", (8)).

In die brief van "Verdrukte Grikwa" (4) verskyn daarom voor tog, moontlik in die sin van 'desondanks' (dus daarom ${ }^{2}$ ) (vb. a); vgl. ook Benigna (9, p.26) (vb. b):

(a) maar die boeren heef eerst in de maand Februari en Maart van dit jaar terug getrek en nu is nog volop gras in de colonie maar zy kome daarom tog weer in dit land, net maar om ons te plaagen.

\footnotetext{
${ }^{13}$ EA beskryf darem as 'n "verswakte vorm (meestal met modale funksie) van Ndl. daarom in die verouderde betekenis 'tog, nieteenstaande dat"'.
} 
(b) "maar al mot ons op Groenekloof oue schoene eet dan zel ons daarom daar blij, want ons wil Gods Woord leer"

In $(9$, p.48) word van twee welgestelde persone ("huisbezitters") gesê: "hulle verzuim nooit nie een kerk nie, en hulle is daarom nie armer als ons nie", en: "hulle help voor ieder arme mens ook, en hulle is daarom getrouw bij die kerk". Die hipotaktiese verband is hier duidelik $\left(\right.$ daarom $\left.^{2}\right)$, maar dit gaan ook daarom dat die verwagting van die spreker oortref is $\left(\right.$ darem $\left.^{1}\right)$. Al kan daarom in die volgende (p.66) ook 'desondanks' wees, is iets van darem ${ }^{1}$ aanwesig blydskap oor die feit dat sy nog leef: Nadat 'n bejaarde moeder vertel "Mijn ligchaam is om zo te zeg al dood, en mijne kinders het maar las van mij", antwoord haar oudste seun: "Ons is daarom ook blij, dat moeder nog bij ons is."

Die volgende drie daarom-gevalle is al drie uit dieselfde teks in De Bode (8, p.35) van Sept. 1864. Daarom in (i) verteenwoordig darem $^{1}$ ('minstens') en in (ii) en (iii) darem ${ }^{2}$ ('regtig'):

(i) "Ik weet nie of hij kan lees nie, ... maar hij is daarom in de boeke geleer"

(ii) "Nee, ... ons doen daarom nie altoos zoo nie."

(iii) "Dat is waar wat Baas zee, maar een deugniet hoef hij moes daarom nie te wees nie."

Darem/ daem in die volgende verteenwoordig $\operatorname{darem}^{1}$ ('minstens'):

da praat hulle nog darem sô, sô die taal hy's darem sô nog die tal vir ons (GAK (11), p.613)

ons het daem nog 'n klompie oorgehad (GAK(11), p. 620)

Ek kan darem sê waar ek stam (GAK(11), p.631)

Die volgende is uit (12):

Ja, ja, hier rondom die tkaia vat ek nie kierie darem nog nie maar hier is darem kol-kol mooi granetjies

Juis, dat daar darem 'n geldjie kan inkom

Darem/dam in die volgende verteenwoordig darem ' ('regtig'), ook 'n fokuspartikel:

nou ry die boer dam baie lekker (GAK (11), p. 589)

hulle [= die blomme] is darem nie daardie jaar s'n. (12)

\section{Ndl. zo maar en Afr. sommer}

Sommer en sy wisselvorme maak $30 \%$ uit van die partikels in die Griekwa-korpus waarna gekyk is (vgl. Tabel 2). Dit is moeilik om die gebruike van Ndl. zo maar en Afr. sommer skerp van mekaar te onderskei. Betekenisonderskeidings wat vir Nederlands aangegee word, dek die meeste Afrikaanse gebruiksgevalle. PWN verklaar byvoorbeeld zo maar as 'zonder bijbedoeling, aarzeling of reden', GK zomaar as 'onvoorbereid, een twee drie, eenvoudigweg, zonder aanleiding': je kan toch niet zomaar wegblijven. Zoo maar is temporeel ('een twee drie, eensklaps') in 
Toen was die boer zoo maar stil en zeg niks nie (9, p. 53).

GWHN gee 'zonder in- of aanleiding' as eerste betekenis; sy tweede betekenis, 'zonder beperkingen' (kan dat hier allemaal zomaar), is miskien nie tipies van Afr. sommer nie. Sommer as 'sonder rede' of 'sonder aanleiding' vind ons terug in die brief van "Verdrukte Grikwa” (18):

maar ik denk tog dat de governeur ook niet zoma een volk zal oordeel.

$i k$ geloof mynheer zal niet zo mar alles aanneem wat ...

Dit wil voorkom asof Afr. sommer semanties uitgebrei het in die rigting van emotiewe en graadmarkering, en dan veral in die funksie van fokuspartikel vir emotiewe woorde en uitdrukkings. Vergelyk die afkeuring wat spreek uit die volgende uit die SK:

Hel, dis sommer nonsens daardie

Ek is sommer vies daaroor, jy weet

Sommer/soo maar kom veral veelvuldig in die Griekwa-korpus voor (30\% van die modale partikels, nоu en dan uitgesonder), asook in die tekste. In die volgende fokus sommer, ens., die aandag op iets wat reeds beklemtoon word of 'n hoë graad aandui, byvoorbeeld:

Toe's ik nog sommer baie jong (GAK, p.751)

Hille is sommer kjeenners teen my, baas (GAK, p.859)

Sy's nou sommer jare al weg hier (GAK, p.696)

Hase was volop. Die't ons sommer so twee, drie, vier op 'n dag gevang (GAK, p.754)

$\mathrm{Ja}$, dis sleg [= die woord tkaboe], maar sommer sleg, lelik, onlieflik. (12, p.105)

$i k$ wens zo maar dat tog alle mensen die lieve Heer Jesus mog lief krijgen (2)(brief van Jan Bastert).

Sommer, ens., kan ook direk of by implikasie as graadaanduider optree:

gestool! gestool! sjeur maak en mensch zoo maar kwaad. (3, p.39)

Hy's vasgesyg man. Hy's sommer vas. (GAK, p.580)

Hy's sommer stérk darie broek (GAK, p.759)

\section{Maskie}

Maskie kom volgens Hesseling (1923:47) herhaaldelik in die Kaapse stukke voor, meestal in die vorm maski (masky) en met die betekenis: 'wat dan nog'. Roberge (2002a:94) ${ }^{14}$ wys daarop dat dit afkomstig is van Kreool-Port. maski, Port. mas que, en volgens hom beteken dit 'never mind, perhaps, (even) if.' Die teenstellende 'even if' vind ons ook in Den Besten (Van der Wouden 2012:103) se vertaling van masqui ophangen, ick ben niet bange as 'Even if I am hanged, I am not afraid.' Changuion (1848:xvii), wat maskie in sy woordelys ook teenstellend beskryf as 'al is het ook', met die voorbeeld maskie is ik ziek, ik wil nie t'huis blij'nie 'al ben ik ook ziek, ik wil niet te huis blijven', beskou dit as 'n sametrekking uit het mag geschiên. Laasgenoemde is egter volgens FEW juis die etimologie van misschien:

\footnotetext{
${ }^{14}$ Vir 'n uitvoerige bespreking van maskie, vgl. Roberge (2002b).
} 
tmachscien < het + mach 'kan' + scien 'geschieden'. Die [a] in 'n vroeër vorm soos masscien open die moontlikheid van verwarring met maskie, waarvan daar wel aanduidings is.

Sonder om die Portugese herkoms - en daarmee slaweherkoms - van maskie te ontken, is dit tog duidelik dat die woord vroeg reeds by die Khoi-Khoin inslag gevind het. Maskie is reeds in 1671 deur Kolbe in die vorm mashy opgeteken (vgl. Raidt 1991:125):

Duytsman altyt kallom: Icke Hottentots doot makom. Mashy doot, Icke strak nae onse groote Kapiteyn toe ...

B. Farrington se vertaling van hierdie gedeelte in Ten Rhyne lui soos volg (Schapera en Farrington 1933:141): "Dutchmen always say: I will kill Hottentots. Well, kill! If I die, I shall go straight to our Great Chief." Den Besten gee die laaste gedeelte weer (Van der Wouden 2012:102) as: 'Despite die, I FUT to our big Chief (to)'. Kolbe (1727(I):491) kry op 'n stelling wat hy maak, die reaksie: Duitsman ja musku slim, ons al te maal verraden, wat hy weergee as: "de Duitschers of Europeanen zyn ons al te sno ${ }^{15}$, zy zullen onzen gantschen handel verraden". 16

Veel later word Hendrik Kok in die mond gelê (3, p.37): Hy zeg hy het dit gehoor. Ik zeg maskie gehoor, sjeur, dan het hulle voor sjeur een leuge wys gemaak. Terwyl ons hier ook die teenstellende betekenis het (teenstelling met iets wat na die spreker se mening nie klop met die waarheid nie), kan Kaatje Kekkelbek se maskie (5, p. 69) op 'n verwarring met miskien dui: jy kan myn g'loo dat die ouw dikke kerel zyn brandewyn lekker is! maskie ouw Pratt zyn ook. In 'n Griekwa-voorbeeld (11), Dan maskien jy sjee hom 'n rand, is dit eerder 'miskien', ofskoon daar ook 'n teenstellende element is.

\section{Ander partikels}

\section{$\operatorname{Reg}(t)$, regte}

$\operatorname{Reg}(t)$ en regte kom enkele male adverbiaal voor, as 'rêrig, werklik', of adjektiwies, as 'werklike, ware' (vgl. in 'n brief van Sabiena Zeekoeygat (6, p.118): hier was een regte groote bakleislag; dat die ou baas advookaat die avond (foei tog) regte dronk was.) Kaatje Kekkelbek (5, p.68) sê van 'n sluk brandewyn: dan smaak hy reg lekker! en Regt, jong! I wish toch dat de Mist-in-wary Syety would send me to England to speak de trut (sic). Witbooi (10, p.16) verklaar: Maar ik krijg regte hartzeer als ik hoor dat... In De Bode (8) lees ons: dat is een regt verkeerde naam; en weet hem regt geen raad. "Verdrukte Grikwa" (4) beweer: ik denk dat mensche veel jaar nodig het om regt beschaaft te word. Die reduplikasievorm (vgl. Conradie 2011) vind ons by Hendrik Kok (3, p.38): ik zal voor sjeur nou regreg zegge hoe het toegegaan is.

\section{Juist}

Juist word in "Kaatje Kekkelbek" (5, p.69) twee maal gebruik in die sin van Eng. just (vgl. Dat Engels dam, was juist de same en De Tronk, it is een lekker plek / Of t'was not juist so.)

\footnotetext{
${ }^{15}$ Moontlik van snood, wat 'slecht, boos, misdadig' of 'schrander' kon beteken (VD).

${ }^{16}$ Verraden: 'verlore laat gaan, of: 'aan die lig bring wat geheim moes bly'.
} 


\section{Kamma/kasta}

Kamma (ook kasta) dui op 'n persoon of saak wat anders voorkom of voorgestel word as wat dit/hy/sy werklik is. EA (onder kamma) lei dit af van Khoi khama 'soos'. In Sabiena Zeekoeygat se brief (6, p. 118) tree kasta as adjektief op: hulle zeg hy is zoo een kasta Magistraat. In GAK vind ons: Hier skrou hei kamma van bô af ... In 'n Links-onderhoud word so gereageer (12, p.103-4): Toe sal hy kamma trek kom. Hy kom nou nog. Ook die winter wat kenmerke van die lente vertoon, is skuldig aan "wanvoorstelling": Kyk, dis nou kamma winter maar ons het blomtyd gehad. (12, p.104).

\section{Hoeka}

Hoeka is, soos kamma, 'n Khoi-bywoord van tyd (Planert 1905:23 beskryf Nama hŭga as 'von jeher', NW beskryf huga en huga-eibe as 'von jeher, von altersher') wat modale waardes ontwikkel het in Afrikaans. Dit is daarom verbasend dat hoeka net een maal voorgekom het in die Khoi-Khoinbronne wat ondersoek is, en daar moontlik slegs as tydsaanduiding: Hier ... het mos hoeka min mens gekom (12, p.105).

\section{Netnou}

Die tydsbywoord netnou is besig om in Afrikaans te ontwikkel in 'n voorspelling-cumwaarskuwing. Hierdie ontwikkeling kan ook in die Griekwa-korpus (11) waargeneem word: vgl.: die ouwaas moet my petaal vamirrag. Net-nou is ek en die ouwaas an mekaar.

\section{Samevattende waarnemings}

Kyk ons na al die grootste tekste van voormalige Khoisprekers (vgl. Tabel 1), dus veral die Griekwa-onderhoude, maar ook die "onderhoud" met Hendrik Kok, die dialoog in Benigna, die briewe van Hendrik Witbooi en die Kharkams-onderhoude, dan blyk dit dat mos verreweg die meeste by Kok, die Griekwas en in Kharkams voorgekom het, terwyl tog in Benigna en by Witbooi die meeste voorgekom het, en in 'n mindere mate by Kok. Dit is opvallend dat tog veral sterk staan in oorredende tekste met sterk Nederlandse invloed of konteks. Mos staan weer baie sterk in tekste met spreektaalkenmerke, met name almal in 'n onderhoudregister. Sommer is 'n sterk tweede by die Griekwas. Maar as modale partikel is in al hierdie tekse in 'n mindere mate aanwesig, ofskoon tweede by Benigna. Darem is in Benigna, by die Griekwas en in Kharkams aanwesig, maar maak telkens minder as $10 \%$ van die ondersoekte partikels uit.

Kyk ons na die kontroleteks (13), is dit opvallend dat maar sterker staan as mos en dat eintlik relatief belangrik is, maar darem nie noemenswaardig meer frekwent voorkom as in die KhoiKhoinbronne is nie. Die Kanna-drama wyk van al hierdie bronne af deur die meeste van darem gebruik te maak, met maar en mos in die tweede plek.

As ons onderskei tussen Nederlandsverwante partikels soos eintlik, maar en tog, enersyds, en tipies Afrikaanse partikels soos darem, mos en rêrig, dan blyk dit dat eersgenoemdes oorwegend voorkom in Benigna (9) en in die kontroleteks (13), en laasgenoemdes oorwegend by Hendrik Kok (3), die Griekwas (11), Kharkams (12) en Kanna (14). In die egte onderhoude met Khoi-Khoin $(11,12)$ en 'n gefabriseerde onderhoud (3), wat almal die spreektaal voorstel of verteenwoordig, is tipies Afrikaanse partikels derhalwe in die meerderheid. 
Kollokasies, dit wil sê kombinasies, selfs van meer as twee partikels is gebruiklik in tale soos Nederlands en Duits, maar ook in Afrikaans. As ons die twee korpusse, die Griekwakorpus (11) en die kontrolekorpus (13) vergelyk, vind ons heelwat voorbeelde van kollokasies in albei. 'n Opvallende verskil is egter dat eersgenoemde mos nou as verreweg die frekwentste kollokasie het, maar laasgenoemde veral maar net en nou maar. Die hoë frekwensie van mos nou in die Griekwakorpus het moontlik te make met verskille in die onderhoudsituasie: mos nou hang saam met 'n taktvolle manier om op moeilike vrae te antwoord, veral waar kultuurverskille ter sprake is of 'n gemeenskaplike agtergrond ontbreek.

$J a$ kom in van die oudste aanhalings (vgl. (1) en (2)) as modale partikel voor. In ses gevalle kan dit 'n ekwivalent van 'immers', 'mos' of 'tog' wees en in vyf gevalle 'n fokuspartikel of emfaties wees. Omdat al die latere Khoi-Khointekste oorheers word óf deur mos, óf - miskien in samehang met Nederlandse invloed - deur tog, is daar 'n saak voor uit te maak dat veral mos by die Khoi-Khoin 'n leemte vul wat deur ja gelaat is. Omdat mos ook sterk staan in die kontrolekorpus (13) en by Kanna (14) is die gegewens egter onvoldoende om die ontwikkeling van mos as modale partikel slegs aan (voormalige) Khoisprekers toe te skryf.

In moderne Afrikaans verskil daarom en darem duidelik as "voegwoordelike bywoord" en subjektiewe modale partikel respektiewelik. In Benigna (9) en enkele ander geskrifte met 'n Genadendalse oorsprong (8) word slegs die vorm daarom gebruik, maar soms met 'n betekenis wat dié van darem benader. Verdere ondersoek van Genadendalse bronne kan moontlik lig werp op die proses van differensiasie tussen daarom en darem.

Al verskil Afr. sommer nie sterk van Ndl. zo maar nie, is daar tog in verskeie van die KhoiKhointekste aanduidings van 'n ontwikkeling in die rigting van emotiewe en graadmarkering, en die funksie van fokuspartikel vir emotiewe woorde en uitdrukkings. Maskie het 'n KreoolsPortugese oorsprong, maar kom van vroeg af ook by die Khoi-Khoin voor. Die moontlikheid van 'n verwarring of konvergente ontwikkeling met miskien, vroeër ook maschien, kan nie uitgesluit word nie. Die bywoord $r e g(t)$ en die adjektief regte, voorlopers van die reduplikasievorm reg-reg en daaruit voortspruitende rêrig, kom ook meermale by die KhoiKhoin voor. Van juist is daar by Kaatje Kekkelbek twee voorbeelde van 'n weergawe van Eng. just. Kamma, wat waarskynlik van Khoi afkomstig is, word in 'n aantal KhoiKhoinbronne aangetref, asook een maal die wisselvorm kasta in adjektiwiese funksie. Hoeka, as tydsbywoord afkomstig uit Khoi (vgl. Nama huga) met 'n ontwikkeling as modale partikel in Afrikaans, is verbasend genoeg net een maal in 'n onderhoud aangetref. Netnou, nog 'n tydsbywoord wat 'n modale funksie in Afrikaans ontwikkel het, is in die Griekwa-korpus in dié funksie aangetref.

Samevattend kan gestel word dat voormalige Khoisprekers te oordeel na gebruiksfrekwensie en die gebruik van tipies Afrikaanse partikels, 'n deurslaggewende rol gespeel het in die ontwikkeling van Afrikaanse modale partikels.

\section{Afkortings}

EA: Van Wyk 2003

FEW: Van Wijk 1979

GAK: Van Rensburg 1984

GK: Koenen en Drewes 1986 
GWAN: Martin 2011

GWHN: Van Sterkenburg 2002

NW: Rust 1969

PWN: Weijnen en Ficq-Weijnen 1999

SK: Kroes 1982

VD: Kruyskamp en De Tollenaere 1950.

WAD: Trümpelmann \& Erbe 1971

WAT: Schoonees 1974

WNT: Knuttel 1916/ Beets 1926

\section{Verwysings}

Abraham, Werner. 1989. Discourse particles in German: how does their illocutive force come about? In W. Abraham (red.). Discourse Particles. Amsterdam: John Benjamins. 203-252.

Benigna van Groenekloof of Mamre. 1873. Door een hunner leeraars. Genadendal. Changuion, A.N.E. 1848. De Nederduitsche taal in Zuid-Afrika hersteld. Rotterdam: J. van der Vliet.

Conradie, C.J. 1995. Die partikel mos: 'n semantiese verkenning. SA Tydskrif vir Taalkunde, Supplement 28 ("Hoe beteken dit alles?", red. Anna Coetzee), Nov.:45-55.

Conradie, C.J. 2011. "Is regtig rêrig Duits richtig?" Tydskrif vir Geesteswetenskappe 51(4):716-729.

Dagboek van Hendrik Witbooi, Kaptein van die Witbooi-Hottentotte 1884-1905, die. 1929. Kaapstad: Van Riebeeck-Vereniging no. 9.

Den Besten, H. 2005. Neerlandismen, pidginismen en Afrikaans in brieven van twee Khoekhoen uit 1800. Tydskrif vir Nederlands en Afrikaans 12(1):25-42.

Franken, J.L.M. 1953. Taalhistoriese bydraes. Amsterdam/Kaapstad: A.A. Balkema.

Haeseryn, W., K. Romijn, G. Geerts, J. de Rooij en M.C. van den Toorn. 1997. Algemene Nederlandse spraakkunst. Groningen: M. Nijhoff.

Hesseling, D.C. $1923^{2}$. Het Afrikaans. Leiden: E.J. Brill.

Knuttel, J.A.N. 1916/ Beets, A. 1926. (reds.). Woordenboek der Nederlandsche Taal. 'sGravenhage: M. Nijhoff.

Koch, J. 2006. Herman Benno Marx (1827-1917) - auteur van Benigna van Groenekloof of Mamre (1873). Werkwinkel 1(1):13-42.

Koenen, M.J. en J.B. Drewes. 1986. Wolters' woordenboek eigentijds Nederlands. Groningen: Wolters- Noordhoff. 
Kolbe, P. 1727. Naaukeurige en uitvoerige beschryving van de Kaap de Goede Hoop, Deel I en II. Amsterdam: Balthazar Lakeman.

Kroes, H. 1982. Navorsingsprojek: Die frekwensiebepaling van die kernwoordeskat en sekere strukture van die Afrikaanse spreektaal. Ongepubliseerde navorsingsverslag, Johannesburg: Randse Afrikaanse Universiteit. - "Spontane korpus".

Kruyskamp, C. en F. de Tollenaere. 1950. Van Dale's Nieuw groot woordenboek der Nederlandse Taal. 's-Gravenhage: M. Nijhoff.

Links, T. 1989. So praat ons Namakwalanders. Kaapstad: Tafelberg.

Martin, W. (hoofred.) 2011. Pharos Groot Woordeboek Afrikaans en Nederlands. Kaapstad: Pharos Woordeboeke.

Nienaber, G.S. $1971^{2}$. Afrikaans in die vroeër jare. Johannesburg: Voortrekkerpers.

Planert, W. 1905. Handbuch der Nama-Sprache. Berlin: D. Reimer.

Raidt, E.H. $1991^{3}$. Afrikaans en sy Europese verlede. Kaapstad: Nasou.

Roberge, P.T. 2002a. Afrikaans: considering origins. In R. Mesthrie (red.). Language in South Africa. Cambridge: Cambridge University Press. 79-103.

Roberge, P.T. 2002b. The Modal Elements mos and maskie in Cape Dutch. Language Sciences 24:397-408.

Rust, F. 1969. Nama Wörterbuch. Pietermaritzburg: University of Natal Press.

Schapera, I. en B. Farrington. 1933. The early Cape Hottentots. Kaapstad: The Van Riebeeck Society, no. 14.

Schoonees, P.C. (hoofred.). 1974. Woordeboek van die Afrikaanse taal. Pretoria: Staatsdrukker.

Smal, A. 1989 (1965). Kanna hy kô hystoe. Kaapstad: Tafelberg.

Spontane Korpus, sien Kroes 1982.

Ten Rhyne, W. 1933 (1686). Schediasma de Promontorio Bonae Spei. In I. Schapera en B. Farrington. The early Cape Hottentots. Kaapstad: The Van Riebeeck Society, no. 14.

Trümpelmann, G.P.J. en E. Erbe. 1971. Woordeboek Afrikaans-Duits, Duits-Afrikaans. Pretoria: J.L. van Schaik.

Van der Wouden, T. (red.). 2012. Roots of Afrikaans. Selected writings of Hans den Besten. Amsterdam: John Benjamins. 
Van Rensburg, M.C.J. (red.) 1984. Finale verslag van 'n ondersoek na die Afrikaans van die Griekwas van die Tagtigerjare. Uitgevoer aan die Universiteit van die Oranje-Vrystaat. (Band II, deel 2)

Van Sterkenburg, P. 2002. Groot woordenboek hedendaags Nederlands. Utrecht/Antwerpen: Van Dale Lexicografie.

Van Wijk, N. 1979. Franck's Etymologisch woordenboek der Nederlandsche taal. 'sGravenhage: M. Nijhoff.

Van Wyk, G.J. (red.). 2003. Etimologiewoordeboek van Afrikaans. Stellenbosch: Buro van die WAT.

Wallmann, J.C. 1857. Die Formenlehre der Namaquasprache. Berlyn: W. Herz.

Weijnen, A.A. en A.P.G.M.A. Ficq-Weijnen. 1999. Prisma Woordenboek Nederlands. Utrecht: Het Spectrum. 